\title{
Work and Future Promises
}

\section{Teaching and Researching Finnish Literature in Poland}

In Poland there is a long tradition of studies in Finnish language and culture. This tradition is in the process of renewing itself and is improving all the time. It is worth noting that at present this very tradition contains the strengthening trend of research into Finnish literature. A new generation of researchers has appeared, and their recent work in progress will contribute to future debates in the field of Finnish literary studies.

Finnish studies is a popular subject at Polish universities. The number of applicants to departments of Finnish language and culture is relatively high compared to many other departments of foreign languages studied at universities throughout the country. The popularity of Finnish studies is not only explained by the increase in interest in research (despite the fact that for the writer and readers of this essay research is the most important aspect of all); there is much vibrant business-life interaction between Poland and Finland, and economic collaboration is flourishing. Those young people in Poland interested in Finnish and Finland assume that there is demand in the work market for Finnish-language skills. Fortunately at present there are many reasonable opportunities to study Finnish at university level in Poland, too.

Finnish language and culture is available as an academic subject at three Polish Universities: Warsaw, Poznań, and Gdańsk. The latest addition to the group is the University of Gdańsk, where Finnish language teaching began in the autumn of 2015. The opportunities for success and productivity in the business sphere that such teaching provides are immense. Initially, at least, the Finnish department at the University of Gdańsk must necessarily place great emphasis on practical language skills, though it is of course possible that more research will be conducted here in the near future.

The University of Warsaw and the Adam Mickiewicz University in Poznań represent dustier humanism in terms of Finnish studies: both are traditional seats of learning. In addition to those many students who have graduated in recent years with either a Bachelor's or a Master's degree, both Warsaw and Poznań will have new doctorates in the near future, most of them researching Finnish literature in their dissertation.

In Poland the teaching of foreign languages and literatures at university-level has traditionally come under the purview of philology. The position of Finnish philology ("fennystyka") in university departments depends either on stressing linguistic affinity and the connection to linguistics (as it does, for instance, at the Department of Hungarology in Warsaw and the Department of General Linguistics in Poznań) or geographical position and cultural characteristics (as at the Department of Scandinavian Studies in Gdańsk). Particularly, as with 
the 'Gdańsk model', it is typical in Poland to identify Finland and Finnish with the Scandinavian countries, cultures and languages. For instance, one explanation as to why Finnish studies is so popular at the University of Warsaw might be the fact that there is no Scandinavian studies at all in repertoire of these universities, the logic being that those applicants interested in the cultures and languages of Sweden, Norway, Denmark or Iceland would, as a result of lack of opportunity to study these subjects, choose Finnish studies instead.

Linguistics has established a powerful position in foreign-language philology, and the same holds true with Finnish philology. In terms of language learning, such a position is certainly reasonable. Linguistic knowledge is very helpful when learning a new language, although the basics of strong language skills are grounded in practical language teaching. In the Polish educational system this is evidenced by the large number of contact teaching hours per week, with similarities to school teaching.

In order to write an MA thesis or, particularly, a doctoral thesis in Finnish literature, it is essential that students have excellent Finnish language skills. This is the current state of affairs in Warsaw: during the time in which I have worked here as visiting professor of Finnish literature and culture, it has been a great honour for me to supervise such well-educated graduate and post-graduate students. Being unable to have their thesis supervision in Polish, students have to write their theses either in Finnish or English, which will be the case with some doctoral dissertations. To my mind this is a good thing since, instead of using their mother tongue, students have to use either the language they are studying or the international language of science. It is clear that, when using either Finnish or English, doctoral students will have more audience for their research works on topics in Finnish literature in the initial phase of their study.

All three universities currently have professors in Finnish studies. My post as a visiting professor of Finnish literature and culture in Warsaw will last until the autumn of 2018. Katarzyna Wojan is professor at the University of Gdańsk, and she specialises in the Finnish language. However, from the perspective of the study of Finnish literature in Poland the most considerable academic position is at Poznań, where Bolesław Mrozewicz serves as professor of Finnish literature. His career in teaching, supervising and researching has had great impact on the general activity of research into Finnish literature and culture in the Polish academic field. Furthermore, PhD Łukasz Sommer from the University of Warsaw, who specialises in Finnish cultural history, continues to make a strong contribution to cultural and literary studies within Finnish studies via teaching, supervising, and researching Finnish literature and culture. This is not to forget all those who translate Finnish literature into Polish. For instance, Łukasz Sommer is an active translator of Finnish poetry, and talented translators such as Sebastian Musielak from Poznań play a crucial role in increasing knowledge and awareness of Finnish literature in Poland. 
Finnish studies at the Adam Mickiewicz University place emphasis on Finnish literature more than the courses at the universities of Warsaw and Gdańsk. In Poznań, students can write their theses on a topic related either to language or literature. The majority of students choose literature. In Warsaw, linguistics is a relatively popular selection among graduate students in choosing the topics of their MA theses. Moreover, our profile is such that in addition to language and literature it is possible to write theses on various different themes within the field of cultural studies. For instance, I also supervise some MA theses that do not focus on literature or the themes associated with literary studies.

Nevertheless, the postgraduate students whom I supervise happen to be among the most talented young literary researchers. The profile of the doctoral programme in Warsaw is thus very similar to that at Poznań; it stresses literary research. This is the reason why we in Warsaw and Poznan also feel so comfortable working with each other that we organise joint research seminars every semester. Moreover, the few doctoral students writing doctoral dissertations on Finnish linguistics often take part in these seminars and, in addition to bringing together researchers of literature and culture, this helps to strengthen the common identity of Finnish philology.

It can be said that Finland has been relatively well known in Poland in recent decades. Some research into Finnish literature has also been conducted, notably in Poznań. Since the 2000s one might even speak of something of a 'Finland boom'; one proof of this is Czas Kultury magazine's theme number 'Fiński Syndrom' (2008). The contributors to this supplement are scholars and other agents in Polish cultural life. The articles consider multiple themes around Finland and Finnishness, thus presenting the country and its culture to the reading audience in Poland. Among the list of contributors, one author in particular leads us to a doctoral dissertation in which a Polish researcher has recently published research on Finnish literature. The researcher in question is Katarzyna Szal and the work is her doctoral thesis from 2013: Finnish Literature in Poland, Polish Literature in Finland - Comparative Reception Study from a Hermeneutic Perspective.

Szal's research was conducted in Finland and at a Finnish university (at the University of Eastern Finland). At Polish universities we aim, nevertheless, to publish new doctoral theses on Finnish literature here in Poland. The first goal is to produce new research on contemporary Finnish detective novels and to publish it in Polish. This will be the doctoral thesis by Martyna Kokotkiewicz from the Adam Mickiewicz University. After this, a number of doctoral students under my supervision are due to publish: Ewelina Bator, Joanna ElantkowskaBiałek, Magdalena Dryll, and Justyna Polanowska. Within a couple of years all of them shall publish their doctoral theses in the form of a research monograph. After that, written either in Finnish or English, will be new research on Finnish socialist poetry and its links with socialist realism, research into contemporary Finnish comic strip art, contemporary short stories of the 'new weird' genre in Finnish literature, and historical representations of the women active during the Finnish civil war. 
The state of teaching and research on Finnish literature in Poland is good and holds much promise for the future. But before these promises can be fulfilled, the only promise that can be made is that there is still plenty of work to do.

\section{Author}

Mika Hallila, PhD, visiting professor of Finnish literature and culture, Faculty of Neophilology, University of Warsaw (m.hallila[at]uw.edu.pl). 